\title{
Studi Deskriptif Kualitatif tentang Partisipasi Remaja dalam Keikutsertaan Posyandu Remaja
}

\author{
Hilda Prajayanti, Maslikhah \\ Email : hilda.ragaiza@gmail.com \\ D III Kebidanan, Akademi Kebidanan Harapan Ibu Pekalongan, Indonesia \\ Jl. Sriwijaya No 7 Kota Pekalongan \\ Telp. 081390467033
}

\begin{abstract}
Abstrak
Masa remaja merupakan masa storm and stress, karena remaja mengalami banyak tantangan baik dari diri mereka sendiri (biopsychosocial factors) ataupun lingkungan (environmental factors). Kompleksnya permasalahan kesehatan pada remaja, tentunya memerlukan penanganan yang komprehensif dan terintegrasi yang melibatkan semua unsur dari lintas program dan sektor terkait. Pembentukan Posyandu Remaja diharapkan dapat menjadi wadah untuk memfasilitasi remaja dalam memahami permasalahan kesehatan remaja. Pengumpulan data menggunakan data primer dan data sekunder. Instrumen yang digunakan berupa wawancara. Tujuan Penelitian ini untuk mengetahui gambaran partisipasi remaja dalam keikutsertaan Posyandu Remaja. Penelitian ini menggunakan desain penelitian deskriptif kualitatif dengan pendekatan studi kasus, pengumpulan data menggunakan data primer dan data sekunder. Teknik pengumpulan data menggunakan wawancara mendalam (indepth interview). Instrumen penelitian menggunakan pedoman wawancara. Subjek penelitian terdiri dari Informan utama yaitu remaja yang mengikuti posyandu remaja sejumlah 5 orang. Informan triangulasi sejumlah 2 orang kader dan 1 petugas Kesehatan. Tehnik sampling menggunakan purposive sampling. Analisis data menggunakan Content Analysis (analisis isi). Hasil penelitian diperoleh bahwa kegiatan posyandu remaja meliputi pemeriksaan TB, BB, TD , LILA dan konseling tentang kesehatan reproduksi. Faktor yang mempengaruhi dalam partisipasi posyandu remaja adalah dengan cara memberikan semangat kepada kader, tersedianya fasilitas untuk penyelenggraan posyandu remaja.
\end{abstract}

Kata kunci: partisipasi; remaja; keikutsertaan; posyandu remaja.

\begin{abstract}
Adolescence is a period of storm and stress, because adolescents experience many challenges both from themselves (biopsychosocial factors) and the environment (environmental factors). The complexity of health problems in adolescents, of course, requires a comprehensive and integrated treatment that involves all elements from across programs and related sectors. The establishment of the Youth Posyandu is expected to be a forum to facilitate adolescents in understanding adolescent health problems. Data collection uses primary data and secondary data. The instrument used in the form of interviews. The purpose of this study was to determine the description of youth participation in the participation of the Youth Posyandu. This study uses a qualitative descriptive research design with a case study approach, data collection uses primary data and secondary data. The data collection technique used in-depth interviews. The research instrument used an interview guide. The research subjects consisted of the main informants, namely teenagers who attended the youth posyandu as many as 5 people. The triangulation informants were 2 cadres and 1 health worker. The sampling technique used purposive sampling The data were analyzed using Content Analysis. The results showed that the youth posyandu activities included examination of TB, BB, TD, LILA and counseling on reproductive health. Factors that influence the participation of youth posyandu are by encouraging the cadres, the availability of facilities for the implementation of youth posyandu.
\end{abstract}

Keywords: participation; youth; youth posyandu. 


\section{Pendahuluan}

Masa remaja merupakan masa storm and stress, karena remaja mengalami banyak tantangan baik dari diri mereka sendiri (biopsychosocial factors) ataupun lingkungan (environmental factors). ${ }^{(1)}$

Berdasarkan hasil Survei

Kesehatan Berbasis Sekolah di Indonesia tahun 2015 (GSHS) dapat terlihat gambaran faktor risiko kesehatan pada pelajar usia 12-18 tahun (SMP dan SMA) secara nasional. Sebanyak 41,8\% laki-laki dan $4,1 \%$ perempuan mengaku pernah merokok, 32,82\% diantara merokok pertama kali pada umur $\leq 13$ tahun. Data yang sama juga menunjukkan $14,4 \%$ lakilaki dan 5,6\% perempuan pernah mengkonsumsi alkohol, lalu juga didapatkan 2,6\% laki-laki pernah mengkonsumsi narkoba. Gambaran faktor risiko kesehatan lainnya adalah perilaku seksual di mana didapatkan $8,26 \%$ pelajar laki-laki dan $4,17 \%$ pelajar perempuan usia 12-18 tahun pernah melakukan hubungan seksual. ${ }^{(2)}$

Kompleksnya permasalahan kesehatan pada remaja, tentunya memerlukan penanganan yang komprehensif dan terintegrasi yang melibatkan semua unsur dari lintas program dan sektor terkait. Kebijakan bidang kesehatan terkait pelayanan kesehatan remaja sebagaimana dimaksud Permenkes Nomor 25 Tahun 2014 ditujukan agar setiap anak memiliki kemampuan berperilaku hidup bersih dan sehat, memiliki keterampilan hidup sehat, dan keterampilan sosial yang baik sehingga dapat belajar, tumbuh dan berkembang secara harmonis dan optimal menjadi sumber daya manusia yang berkualitas ${ }^{(3)}$

Pembentukan Posyandu Remaja diharapkan dapat menjadi wadah untuk memfasilitasi remaja dalam memahami permasalahan kesehatan remaja, menemukan alternatif pemecahan masalah, membentuk kelompok dukungan remaja, memperluas jangkauan Puskesmas PKPR, terutama bagi remaja daerah yang memiliki keterbiban

Berdasarkan informasi bahwa Kota Pekalongan baru meresmikan program posyandu remaja di masingmasing wilayah kerja Puskesmas Kota Pekalongan sejumlah 1 posyandu remaja, salah satunya di Posyandu Remaja yang terletak di Kelurahan Banyurip Kota Pekalongan.

Tujuan penelitian ini Untuk mengetahui gambaran partisipasi remaja dalam keikutsertaan Posyandu Remaja.

\section{Metode Penelitian}

Penelitian yang dilakukan merupakan penelitian deskriptif kualitatif. Penelitian deskriptif adalah suatu metode penelitian yang dilakukan dengan tujuan utama untuk membuat gambaran atau deskripsi tentang suatu keadaan atau area populasi tertentu yang bersifat faktual secara objektif, sistematis, dan akurat. (3)

Penelitian deskriptif kualitatif adalah penelitian yang menggambarkan sifat sesuatu yang tengah berlangsung pada saat studi yang bertujuan untuk memahami fenomena atau gejala sosial dengan lebih menitikberatkan pada gambaran yang lengkap tentang fenomena yang dikaji. ${ }^{(4)}$

Populasi pada penelitian ini adalah seluruh remaja di Posyandu Remaja Kelurahan Banyurip Kota Pekalongan.

Teknik sampling dalam penelitian ini adalah dengan purposive sampling yaitu teknik penentuan sampel dengan pertimbangan tertentu. Caranya yaitu dengan mengambil orang-orang terpilih yang dipertimbangkan dapat memberikan informasi atau data yang yang diperlukan. Selanjutnya 
berdasarkan informasi atau data yang diperoleh dari sumber data sebelumnya, peneliti dapat menetapkan sumber data atau subjek penelitian lainnya yang dipertimbangkan akan memberikan data yang lebih lengkap.

\section{Hasil dan Pembahasan}

Berdasarkan data yang diperoleh dengan pengumpulan data wawancara mendalam dilakukan pada 5 orang informan utama yaitu remaja yang mengikuti posyandu remaja dan 3 orang informan triangulasi, yaitu 1 Petugas kesehatan dari Puskesmas Buaran, 2 orang kader. Adapun karakteristik informan utama dan informan triangulasi dapat dilihat :

Tabel 1 Karakteristik Informan Utama (Remaja)

\begin{tabular}{ccccc}
\hline No & Kode informan & Umur (thn) & $\begin{array}{c}\text { Pendidikan } \\
\text { Terakhir }\end{array}$ & Status \\
1 & IU R1 & 14 & MTs & Siswa \\
2 & IU R2 & 18 & SMA & Mahasiswa \\
3 & IU R3 & 15 & SMP & Siswa \\
4 & IU R4 & 14 & MTs & Siswa \\
5 & IU R5 & 14 & MTs & Siswa \\
\hline
\end{tabular}

Berdasarkan tabel 1 menunjukkan bahwa informan utama dalam penelitian ini berjumlah 5 (lima) remaja di wilayah Kelurahan Banyurip. informan utama berusia 14 - 18 tahun, pendiidkan terakhir antara SMP (Sekolah Menengah Pertama ) dengan SMA (Sekolah Menengah Atas). dengan status siswa dan mahasiswa. Informan utama adalah remaja, dimana masa remaja adalah masa transisi, mereka masih mencari jati diri dan rasa ingin tahu yang lebih tinggi sehingga masa ini merupakan masa yang harus didampingi oleh orang -orang yang memiliki pengetahuan dan sikap yang benar tentang sesuatu hal. Masa ini berkisar antara usia 10-24 tahun.

Sependapat dengan WHO (World helath Organization) yang menyebutkan bahwa yang dikatakan remaja adalah mereka yang berada pada tahap transisi antara masa kanakkanak dan dewasa. Batasan usia remaja menurut WHO adalah 12 sampai 24 tahun. Menurut Menteri Kesehatan RI tahun 2010, batas usia remaja adalah antara 10 sampai 19 tahun dan belum kawin.

Tabel 2. Karakteristik Informan Triangulasi Kader Posyandu Remaja

\begin{tabular}{ccccc}
\hline No & $\begin{array}{c}\text { Kode } \\
\text { Informan }\end{array}$ & $\begin{array}{c}\text { Umur } \\
\text { (thn) }\end{array}$ & $\begin{array}{c}\text { Pendidikan } \\
\text { Terakhir }\end{array}$ & Status \\
\hline 1 & IT.KD1 & 22 & SMK & Pengajar BKBM (paket C) \\
\hline 2 & IT.KD2 & 21 & SMA & Pelajar \\
\hline
\end{tabular}

Berdasarkan Tabel 2 menunjukkan bahwa usia informan triangulasi kader posyandu remaja berusia 21 dan 22 tahun, dengan tingkat terakhir SMA atau sederajat. Status pekerjaan adalah pengajar paket $\mathrm{C}$ dan pelajar.
Kader posyandu remaja dalam penelitian ini diambil dari aktivis yang berkecimpung di organisasi IPNU dan IPPNU, sehingga usia kader posyandu dilihat dari usia bukan lagi termasuk remaja. Akan tetapi dengan pertimbangan bhawa orang tersebut 
dianggap mampu mengelola dan dapat mengajak remaja untuk berpartisipasi dalam kegiatan posymadu remaja, sehingga dipilihkan oarng-orang tersebut. dan mereka memiliki pemikiran yang lebih dewasa dibandingkan dengan peserta posyandu remaja.
Tidak sependapat dengan Kemenkes RI, 2018 yang mengatakan bahwa Kader Posyandu remaja diambil dari remaja yang memiliki kriteria sebagai berikut berusia antara 10-18 tahun, mau secara sukarela menjadi kader dan berdomisili di wilayah posyandu tersebut.

Tabel 3. Karakteristik Informan Triangulasi Kepala Puskesmas

\begin{tabular}{cccccc}
\hline No & $\begin{array}{c}\text { Kode } \\
\text { informan }\end{array}$ & $\begin{array}{c}\text { Umur } \\
\text { (thn) }\end{array}$ & $\begin{array}{c}\text { Pendidikan } \\
\text { Terakhir }\end{array}$ & Pekerjaan & Jabatan \\
\hline 1 & IT.TK & 33 & $\begin{array}{c}\text { Deperawtan } \\
\text { Gigi }\end{array}$ & PNS & $\begin{array}{c}\text { Koordinator Posyandu } \\
\text { Remaja }\end{array}$ \\
\hline
\end{tabular}

Berdasarkan tabel 3 menunjukkan bahwa Informan Triangulasi tenaga kesehatan berusia 33 tahun, memiliki latar pendidikan D3 Keperawatan Gigi, pekerjaan PNS (Pegawai Negeri Sipil) dan menjabat sebagai koordinator posyandu remaja.

Tenaga Kesehatan yang mengkoodinir kegiatan posyandu remaja adalah orang yang memiliki pendidikan minimal d3 kesehatan, sehingga orang tersebut dianggap cukup dan mampu untuk menjadi koordinator posyandu remaja

Sesuai dengan Undang-undang Republik Indonesia Nomor 36 Tahun 2014 tentang Tenaga Kesehatan bahwa setiap tenaga kesehatan harus memiliki ualifikasi pendidikan paling renfah Diploma III di bidang kesehatan.

Partisipasi remaja dalam keikutsertaan posyandu remaja meliputi:

a. Kegiatan di Posyandu Remaja

Kegiatan posyandu remaja berupa pemeriksaan tinggi badan (TB), Berat Badan (BB), tekanan darah (TD), Lingkar lengan Atas (LILA) dan konseling tentang kesehatan sebagaimana terkutip dalam kutipan wawancara berikut ini :
"Konseling tentang mentrusiasi kalo pemeriksaannya Pengukuran TB,BB,LILA ,TD,” (IU R1)

“....Ya seperti saat ini ya Menimbang, mengukur TB, trus ada pelatihan cuci tangan .... " (IU R2)

"Emm..... apa ya itu Mengukur BB,TB,LILA,lingkar perut, TD itu di ukur tesi darah" (IU R3)

"Kegiatan menimbang Mengukur BB,TB,LILA,lingkar perut, TD dan lain lain " (IU R4)

"Mengukur ketinggian BB, dan ......." (IU R5)

Seperti halnya diakui oleh informan triangulasi 2 kader posyandu remaja (IT KD) dan petugas kesehatan (IT TK) mengatakan partisipasi remaja di Posyandu remaja adalah remaja yang berusia antara 10-18 tahun, pelaksanaan kegiatan berupa mengukur $\mathrm{BB}$ dan $\mathrm{TB}$, serta menjaga tubuh tetap ideal dan tidak gizi buruk dan adanya konseling untuk remaja. seperti dalam kutipan dibawah ini : 
“....... bagaimana dia datang biar tahu kesehatannya sendiri dan mungkin ada konseling ......(IT.TK)

“..Hari ini masih Pengukuran BB, TB , lingkar perut dan LILA baik laki laki maupun perempuan ya sama yang urur dari teman teman kader dimulai dari registrasi dulu... (IT.KD1)

“... baru jalan 2 hari kayak Pengukuran BB, TB, lingkar perut dan LILA baik laki laki maupun perempuan dan sosialisasi puskesmas dan karna masih ada virus jadi ada cara cuci tangan lah bu .. yaa seperti itu bu ... (IT.KD2)

b. Pelaksanaan Posyandu Remaja Berdasarkan hasil kepada informan utama menyatakan bahwa sebagian besar menyatakan dilaksanakan 1 bulan sekali pada jam 13.00 sampai 15.00 WIB. Seperti dalam kutipan wawancara berikut :

“...Posyandu remaja dilaksanakan 1 bulan sekali di minggu kedua jam 13.00- 15.00 ... (IU 1)

“...Setiap minggu kedua, 1 bulan sekali, ehm.. Jam 13.00 sampe 15.00...” (IU2)

"...Sama seperti 1 bulan sekali minggu kedua hari jumat,... Emm jam 13.0015.00..” (IU3)

Seperti halnya yang
disampaikan oleh informan
triangulasi kader posyandu remaja
yang mengatakan bahwa
pelaksanaan posyandu remaja
berjalan 1 bulan sekali pada
minggu ke 2 pada hari jum'at
minggu ke 2 jam $13.00-15.00$.
Seperti kutipan wawancara
berikut:

“ ...2 minggu sekali berarti dalam 1 bulan 2 kali, Mulai Jam 13.00 15.00..(IT.KD1)

“ Ee..Berjalannya sebulan sekali minggu kedua, Biasanya siang Jam 13.00 - 15.00 karna itu sibuk biasanya anak anak pada nariahan kalo jumat kan waktunya libur madrasah (IT. $\mathrm{KD} 2$ )

“...Untuk posyandu remaja kemaren sudah di sepakati Jumat minggu kedua, Jam 13.00 - selesai... (IT TK)

\section{c. Partisipasi Posyandu Remaja} Posyandu remaja di kelurahan Banyurip didapatkan hasil bahwa sebagian besar informan utama menyatakan dalam kegiatan Posyandu remaja yang ikut berpartisipasi yaitu Tenaga Kesehatan, remaja IPNU dan IPPNU dan proses pelaksanaan kegiatan dalam posyandu remaja dari pendaftaran, pemeriksaan TB, BB, LILA dan TD serta konseling tentang kesehatan remaja. hasil ini seperti tercantum dalam kutipan wawancara berikut :

"Yang berpartispasi aktif ya.....Ya Remaja, terusan dari tenaga kesehatan, IPNU, IPPNU kalo proses pelaksanaan nya...Pertama Pendaftaran, setelah daftar nanti kita di periksa pemeriksaan TB,BB,LILA,TD, setelah itu dapet bimbingan kesehatan..."(IU1)

“..... anak anak sini ya .....Usia $10-18$ tahun, ada tenaga kesehatannya..... prosesnya Mengisi daftar hadir tapi karna tadi petugas belum dating kayak celingak celinguk, trus abis daftar TB,BB TD,LILA,lingkar lengan".......(IU2)

“...Ya Remaja, trus ada tenaga kesehatan, IPNU , IPPNU... Prosesnya nulis identitas, trus TB,BB TD,LILA,lingkar lengan”..(IU3)

Sependapat dengan yang disampaikan oleh informan triangusi kader posyandu remaja 
dan tenaga kesehatan yang menyatakan bahwa partisipasi aktif dalam kegiatan posyandu remaja adalah kader posyandu, karang taruna, he.emm iya itu juga dari IPNU, dan IPPNU dan menyatakan proses pelaksanaan kegiatan posyandu remaja Melakukan registrasi, setelah itu pengukuran BB,TB,lingkar perut, dan LILA. Seperti dalam kutipan wawancara berikut ini :

“....Emmm dari pengurusan apa tim Anggota tim kader posyandu, karang taruna, he.emm iya itu juga dari IPNU, dan IPPNU setempat. Termasuk dari para remaja juga.. Eee apa tahap tahapannya berarti pertama Melakukan registrasi, setelah itu pengukuran BB,TB,lingkar perut, dan LILA sudah itu semntara belom ada konseling... (IT.KD1)

..."Usia 10-19 tahun, kebanyakan si itu bu dari IPPNU,IPNU dari warga ....... Kalo prosesnya kita si emang butuh apa ya namanya itu ...... pemeriksaan BB,TB dan lainnya ....(IT.KD2)

“....Terutama yang aktif dalam posyandu remaja Remaja IPNU, IPPNU, karang taruna yang bekekrja sama dengan posyandu juga karang taruna yang bekerjasama dengan posyandu ini...” (IT. TK)

d. Lama mengikuti Posyandu Remaja

Berdasarkan hasil wawancara diperoleh hasil bahwa Sebagian besar menyatakan baru pertama kali mengikuti kegiatan posyandu remaja dan 1 (satu ) informan utama sudah pernah mengikuti sebelumnya, kebanyakan yang datang ke posyandu remaja adalah remaja IPNU dan IPPNU, mereka datang ke posyandu reamaja karena diajak oleh teman dengan motivasi untuk mngetahui kesehatan meliputi pemeriksaan $\mathrm{TB}, \mathrm{BB}$, LILA dan TD serta konseling tentang kesehatan remaja, kemudian hal yang menarik untuk mengikuti posyandu remaja adalah untuk mengetahui kesehatan dan postur ideal tubuhnya. dan disampaikan juga bhawa tidak ada hal yang kurang menarik hanya pesertanya Seperti terkutip dalam wawancara berikut ini :

“......Baru sekali yang kemaren belum yang ngajak kesini teman... Alasane biar tau BB sama TB.. kalo untuk tertarik soalnya di lainnya belum ada seperti ini ..kalo hal yang kurang menarik ya. eemmmPesertanya sedikit biasane do lungo dewe dewe remajane....(IU1)

“.....Iya sudah 2 kali dan yang mengajak Eee ada si rekan wanita kan ikut Oraganisasi IPPNU...... Ya Menarik, karna isaya itu pengen memiliki postur ideal yang normal... (IU2)

“.....Baru Pertama kali.. Emm dari Organisasi IPPNU, di infokan di grup wa .. Ya biar mengetahui BB,TB... menarik ya...Kae Mengukur TB karna jarang. hal yang kurang menarik, tak kira enggak ada..(IU3)

Posyandu remaja di

kelurahan Banyurip baru terbentuk dan berjaan 1 bulan yang lalu, sehingga beberapa remaja baru mengikuti posandu remaja untuk pertama kalinya. Selain itu ada sebagian remaja juga tidak mengetahui adanya posyandu remaja

e. Manfaat Posyandu Remaja

Partispasi remaja yang akan dibahas dalam penelitian ini adalah partisipasi remaja dalam kelompok Posyandu Remaja dilihat dari bentuk-bentuk partisipasi serta kegiatan-kegiatan, dimana remaja mengikuti kegiatan-kegiatan yang dilaksanakan di dalam kelompok remaja. Untuk mengetahui partisipasi remaja dalam 
mengikuti kegiatan Posyandu remaja dapat dilihat dari hasil penelitian yang peneliti peroleh di kegiatan-kegiatan yang telah dilaksanakan oleh remaja. Hasil penelitian ini merupakan gambaran tentang bagaimana partisipasi Posyandu remaja dapat bermanfaat bagi remaja yaitu untuk mengerahui status kesehatan dan posyandu remaja dapat menyelesaikan masalah kesehatan pada remaja khususnya remaja putri meliputi masalah gangguan menstruasi, penyakit yang sering dialami remaja. Oleh karena itu diperlukan suatu kesepahaman dari seluruh penduduk terkait dalam melaksanakan kegiatan-kegiatan yang ada di Posyandu remaja untuk meningkatkan kesadaran tentang kesehatan remaja. Seperti tercantum dalam kutipan dibawah ini :

“....Iyaa itu saya dapat mendapat bimbingan tentang diri sendiri trusan dapat mengetahui kesehatan sendiri. ...Periksa kesehatan. Emmm tanggapanya Bagus, agar remaja di banyu urip bisa mengetahui bila terdapat mesalah kesehatan... Emm Membantu, emm contohnya apa ya gitu kudu diet nek gendut..." (IU1)

"....Emm bisa mengetahui seputar kesehatan dan senang bisa mengetahui TB dan darahnya.. Kegiatannya Mengukur TB,BB,cek darah , lingkar panggul,... Iya Dapat karna dapat bisa mengetahuinya tentang kesehatan. Yang saya konselingkan hari ini tentang konsultasi menstruasi lamanya 3 hari itu kenapa.. Membantu, untuk menangani masalah yang terjadi dalam remaja (IU 4)

“...Ya Agar mengetahui kesehatan.. Emm bisa konsultasi apa itu kesehatan dan cara mencegah penyakit. menanyakan masalah diri sendiri seperti mata enggak jelas.. Membantu, untuk menangani masalah yang terjadi dalam remaja “.....(IU5)

\author{
Hal ini diperkuat dengan \\ pernyataan dari informan \\ triangulasi :
}

“.....Manfaatnya menurut saya pribadi ada diantaranya anak anak bisa mengetahui kondisi kesehatannya masing masing seperti setelah mengukur BB,TB. Dan rencananya ada konseling biasanya remaja yang $\mathrm{M}$ akan di beri tambah draah..." (IT. KD1)

...”Ya .... dapat mengetahui dirinya ideal atau normal apa tidak.kalo di timbang dan pencatatan kader kalo konseling nya ya nanti ..” (IT.TK)

f. Bentuk partisipasi remaja dalam melaksankan kegiatan posyandu remaja

Berdasarkan hasil

wawancara, observasi, dan dokumentasi yang diakukan oleh peneliti didapatkan data bahwa partisipasi remaja dalam posyandu remaja dilakukan dalam bentuk partisipasi tenaga. Partisipasi tenaga berupa keikutsertaan dalam kegiatan yang diadakan posyandu remaja. Tenaga ini berupa sumbangan secara fisik oleh remaja yaitu menghadiri posyandu remaja, memotivasi teman untuk dapat hadir dan meramaikan kegiatan posyandu remaja. Hal ini disampaikan oleh informan utama sebagai berikut :

“...Mengikuti terus mengajak temanteman untuk partisipasi...(IU1)

“....Ya ikut serta..." (IU2)

Sependapat oleh informan triangulasi Tenaga Kesehatan yang mengatakan bahwa bentuk pasrtispasi dalam kegiatan posyandu remaja adalah menghadiri posyandu dengan rutin. seperti kutipan wawancar berikut ini :

"......Ya bentuknya adalah dengan menghadiri posyandu dengan rutin..." (IT.TK). 
Berdasarkan hasil wawancara dapat diketahui bahwa bentuk partisipasi remaja dalam posyandu remaja adalah menghadiri posyandu remaja, memotivasi teman untuk dapat hadir dan meramaikan kegiatan posyandu remaja.Informan Utama juga mengatakan bahwa bentuk partispasi posyandu remaja sudah dilaksanakan dengan cara datang secara rutin dan mengikuti rangkaian kegiatan posyandu. Hal ini diungkapkan oleh informan utama sebagai berikut :

“... Emm dengan mempromosikan kegiatan pada teman sekitar..” (IU1)

"..Emm Sudah dilaksanakan dengan cara mengikuti seluruh kegiatan posyandu..." (IU2)

seperti yang diungkapkan oleh informan triangulasi kader posyandu remaja yang menyatakan bahwa bentuk partisipasi sudah dilaksankan di Posyandu remaja meskipun ada yang kurang mengikuti. Seperti dalam kutipan wawancara berikut ini :

Bentuk dominan partisipasi dalam kegiatan posyandu remaja yaitu hadir bersama teman teman ke posyandu remaja. Seperti yang diungkapkan oleh informan utama

\begin{tabular}{lll|} 
“...Menghadiri & posyandu & remaja \\
dengan rutin & bersama & teman-- \\
teman....." (IU. 3) & & \\
\hline
\end{tabular}

Hal diperkuat oleh informan triangulasi tenaga kesehatan yang mengatakan bahwa partisipasi apa yang paling dominan dalam kegiatan posyandu remaja dengan menghadiri posyandu rutin dan membentuk kegiatan yang positif dan kreatif. seperti kutipan wawancara di bawah ini :
“.......Ya Dengan menghadiri posyandu rutin dan membentuk kegiatan yang positif dan kreatif.." (IT. TK)

Faktor pendukung yang mempengaruhi partisipasi remaja dalam posyandu remaja

Selama ini keberhasilan Posyandu remaja banyak didukung oleh partisipasi remaja dengan dengan mengajak teman teman untuk mengikuti posyandu. Hal ini yang mendorong remaja turut serta tidak hanya dari dalam tetapi dari luar juga mempengaruhi keberlangsungan kegiatan Posyandu remaja. Seperti yang diungkapkan oleh informan utama sebagai berikut :

“..yang mendukung ya...Emm mungkin ya mengikuti dan mengajak teman teman.." (IU1)

"...Ya emm menghadiri kegiatan dan mengajak teman teman berpartisipasi.." (IU R2).

Disamping itu juga disebutkan bahwa faktor yang mendukung kegiatan posyandu remaja adalah kader posyandu orangnya ramah sehingga memudahkan dalam mengajak seseorang untuk datang ke posyandu remaja, seperti diungkap oleh IU R5 dalam kutipan wawancara berikut :

“....Ya sangat bagus karna Orang
orangnya sangat ramah...” (IU R4)
“....Eee ya karna Orang orangnya
ramah seperti...” (IU R5)

Dari hasil wawancara didapatkan
juga bahwa organisasi yang
bekerjasama dengan posyandu remaja
adalah IPPNU, IPPNU dan tenaga
medis. seperti terkutip dalam hasil
wawancar berikut:
\begin{tabular}{l}
\hline “.....Ya seperti Tenaga medis, ipnu, \\
ippnu...” (IU R1) \\
“....Ya Organisasi IPPNU...” (IUR2) \\
\hline
\end{tabular}

Dukungan dari remaja terhadap posyandu remaja karena adanya niat dari remaja sendiri iuntuk mencari 
informasi tentang kesehatan remaja. seperti yang diungkap oleh informan utama :

“...Ya Mendapat seperti dari kelurahan
,rt,rw...” (IU R1)
“....Mendapat dari kelurahan.. (Iu R3)
“....Ya apa ya Mendapat dukungan
RT,RW , Orang tua...'(IU R4)

Pernyataan ini diperkuat oleh informan triangulasi tenaga kesehatan seperti kutian wawancara dibawah ini :

“....Yaa kita si dapet dukungan ya bu ee. Kayak dari rt sama rw setempat seperti itu bu..." (IT. TK)

\section{Kesimpulan}

Dari penelitian di atas dapat disimpulkan bahwa faktor pendukung kegiatan posyandu remaja adalah: adanya partisipasi remaja dengan dengan mengajak teman teman untuk mengikuti posyandu, adanya semangat dari kader, adanya fasilitas alat yang disediakan untuk memperlancarnya kegiatan posyandu, adanya informasi melalui Wa group, adanya organisasi yang bekerjasama dengan posyandu remaja yaitu IPPNU, IPPNU dan tenaga medis, organisasi kepemudaan IPNu dan IPPNU merupakan salah saru organisasi yang populer dan aktif di kalangan masyarakat banyurip. Dan adanya dukungan dari orang tua, kelurahan, RT dan RT setempat.

Sedangkan untuk faktor penghambat posyandu remaja dapat disimpulkan yaitu: Pelaksanaan Posyandu remaja bersamaan dengan acara keluarga , Kesadaran remaja akan pentingnya posyandu remaja, Faktor teman yang tidak mengikuti posyandu remaja, Kesibukan remaja di kegiatan lain.

\section{Saran}

a. Pemilihan waktu untuk pelaksanaan posyandu remaja harus dengan kesepakatan antara remaja setempat, kader posyandu dan tenaga kesehatan agar peserta posyandu dapat dihadiri lebih banyak remaja.

b. Meningkatkan kesadaran remaja akan pentingnya posyandu kesehatan bagi remaja

\section{Daftar Pustaka}

[1] S. Susanti, H. Apriasih, and T. Danefi, "Pemberdayaan Masyarakat Melalui Pelatihan Kader Posyandu Remaja Uswatun Hasanah Desa Cikunir," ABDIMAS J. Pengabdi. Masy., vol. 3, no. 2, pp. 279-284, 2020, doi: https://doi.org/10.35568/abdimas .v3i2.579.

[2] Kementerian Kesehatan RI, Profil Kesehatan Indonesia 2017. Jakarta: Kemenkes RI, 2018.

http://www.depkes.go.id/resourc es/download/pusdatin/profilkesehatan-indonesia/ProfilKesehatan-Indonesia-tahun2017.pdf (accessed Jan. 31, 2019).

[3] Sulistyaningsih, Metodologi Penelitian Kuantitatif dan Kualitatif. Yogyakarta: Graha Ilmu, 2011.

[4] Sugiyono, Metode Penelitian Kuantitatif, kualitatif dan $R \& D$. Bandung: Alfa Beta, 2011.

[5] S. Fitriani, Promosi Kesehatan, Cetakan 1. Yogyakarta: Graha Ilmu, 2011.

[6] Kemenkes RI, Pedoman Umum Pengelolaan Posyandu. Jakarta: Kemenkes RI, 2011.

[7] H. Djuhaeni, "Motivasi kader meningkatkan keberhasilan kegiatan Posyandu," J. Pascasarj. Ilmu Kesehat. Masy. FK UNPAD MKB, vol. 42, no. 2:140-8, 2010. 